UDK 582.632.2:581.45(497.6 Bosanska krajina)

\title{
VARIABILITY OF THE SWEET CHESTNUT (Castanea sativa Mill.) BASED ON THE MORPHOLOGICAL PROPERTIES OF THE LEAF IN NATURAL POPULATIONS OF BOSANSKA KRAJINA
}

\section{Varijabilnost pitomog kestena (Castanea sativa Mill.) na osnovu morfoloških karakteristika lista u prirodnim populacijama Bosanske Krajine}

\author{
Aida Mujagić-Pašić ${ }^{1}$, Dalibor Ballian ${ }^{2}$
}

\begin{abstract}
An analysis of the morphological properties of the sweet chestnut (Castanea sativa Mill.) leaves has identified the presence of an intra-population and inter-population variability of the sweet chestnut. The material has been collected from 16 subpopulations in the region of Bosanska Krajina (Cazin, Bužim, and Velika Kladuša) and amounted to 4,380 leaves of equal dimensions. Their morphological features - blade length in mm (ŠPL), blade width in $\mathrm{mm}$ (DPL) and petiole length in $\mathrm{mm}$ (DPE) - have been measured. The shape of leaf base and depth of indentations of leaf edges have been established according to the descriptor for the sweet chestnut (UPOV 1989), while the ratios have been calculated based on the known values: leaf blade length/leaf blade width (ŠPL/DPL) and leaf blade width/total leaf length (ŠPL/UDL).

The purpose of this research is to establish intra-population and inter-population variability of the natural sweet chestnut populations in the region of Bosanska Krajina on the basis of leaf morphology.
\end{abstract}

Key words: the sweet chestnut, Bosanska Krajina, morphological features of the leaf, variability.

\section{INTRODUCTION - Uvod}

The Castanea (Fagaceae) genus features seven species which are mainly distributed in temperate regions of the Northern Hemisphere, more specifically in the south-eastern parts of North America, Southern Europe, Northeast Africa and Western and Eastern Asia (FERnANDEZ-LoPeZ AND AlIA 2003). The sweet chestnut (Castanea sativa Miller) represents the only natural species of this genus in Europe, which is widely cultivated for multiple purposes, including the production of nuts, tannin, timber, while it

\footnotetext{
${ }^{1}$ Biotechnical Faculty University of Bihać

${ }^{2}$ Faculty of Forestry, University of Sarajevo
} 
is also used in many countries as a decorative species due to its luxuriant appearance during blossoming.

In Bosnia-Herzegovina, sweet chestnut stands cover the area of around 7,000 hectares and are located at elevations between 150 and 700 metres, with the majority of forest stands located at elevations between 300 and 600 metres (WRABER 1958). When it comes to the origin of the sweet chestnut in Bosnia-Herzegovina, the predominant opinion is that sweet chestnut sites in this region are part of a single autochthonous range stretching from Slovenia through Croatia and BosniaHerzegovina (SuČIĆ 1953, WRABER 1958, Zelić 1998). The most extensive, and consequently, the most important sweet chestnut site in Bosnia-Herzegovina is located in the north-western parts of the country (the region of Bosanska Krajina), where sweet chestnut forests, according to data from 1967, covered around 6,850 hectares, or around $89 \%$ of the total area in the country covered by the sweet chestnut (UsČUPLIĆ AND MIDŽIĆ 1967). Although there is major environmental and economic importance, chestnut is still insufficiently explored and studied species (MUJAGIĆ-PAŠIĆ AND BALLIAN 2011). Previous research of this kind on the territory of Bosnia-Herzegovina is very limited, as it mainly dealt with the pomological properties (MUJIĆ ET AL. 2010, SKENDER 2010), chemical composition of the nut (MUJIĆ ET AL. 2006), and diseases (TREŠTIĆ ET AL. 2009).

It is known that the starting basis for plant breeding is phenotype and genotype variability of the material. The reason for this is the fact that properties complying with the pursued goal can be found only in distinctively variable material. It is also important to be familiar with the relevant taxonomic categories ranked lower than the species, as well as with their natural distribution and variability. Morphological and phonological properties are frequently used in practice to study genetic variability (NEOPHYTOU ET AL. 2007), because they sometimes provide a faster insight into the existence of variability compared to analyses of isoenzymes and molecular markers. Research based on the morphology of the sweet chestnut leaf is still generally accepted in the world, given the fact that the shape, size and anatomy of the sweet chestnut leaf vary considerably in different environmental conditions (BRUSCHI ET AL. 2003) and are suitable for measurements (NEOPHYTOU ET AL. 2007). According to our knowledge, there is no data on the variability of sweet chestnut populations in the region of Bosanska Krajina, thus the results of this study of the intra-population and inter-population variability of the morphological properties of the leaf can serve as the starting point for further research of this species in its natural, as well as a basis for the selection of genetically adequate material for the selection and conservation of natural sweet chestnut populations in Bosnia-Herzegovina. The priority topics which will have to be addressed in the country in the future, when this species is in question, are the integrated and coordinated taxonomic approach to chestnut forests at European level, the impact of the conditions and different management systems on the growth, selection and conservation of the sweet chestnut, optimal methods of pest and disease control, and the use of the species within the climate change context. 


\section{MATERIAL AND METHODS - Materijal i metode rada}

The intra-population and inter-population variability of certain morphological properties of the leaf of the sweet chestnut (Castanea sativa Mill.) were studied in 2009 among the natural populations of the sweet chestnut (Table 1) in Bosanska Krajina (Cazin, Bužim and Velika Kladuša). A total of 16 subpopulations and 140 sweet chestnut trees as well as 6 trees of the "Pelasore" cultivar in the area of Bosanska Krajina (north-western Bosnia-Herzegovina) were selected. The selection of subpopulations made sure that scientifically interesting, minor and local subpopulations are equally represented. The cultivars served as control samples in the studying of the mentioned properties of the sweet chestnut. 30 leaves were collected from each tree, from fertile short shoots and the southern parts of the tree top. Primary selection was used in the collection of the material in which leaves of equal dimensions with distinguished properties to be measured/analysed were selected, both for leaves within a single tree and for leaves within the same subpopulation. A total of 4,380 leaves were collected. The leaf material was dried with the standard procedure of herborization in newsprint. Variables of the leaf measured were blade length in $\mathrm{mm}$ (DPL), blade width in $\mathrm{mm}$ (ŠPL), petiole length in $\mathrm{mm}$ (DPE), and the derived properties according to the descriptor for the sweet chestnut (UPOV 1989): leaf base shape - property 21 and depth of indentations of leaf edges - property 22. According to SERDAR ET AL. (2011) and based on the known values, the following ratios were calculated: leaf blade length/leaf blade width in mm (ŠPL/DPL) and leaf blade width/total leaf length in mm (ŠPL/UDL). The properties of the leaves were measured on millimetre paper with a $1 / 10$ $\mathrm{mm}$ precision, while other properties were estimated visually.

Table 1. Investigated subpopulations of sweet chestnut (Castanea sativa Mill.) in Bosanska Krajina Tablica 1. Istraživane subpopulacije pitomog kestena (Castanea sativa Mill.) u Bosanskoj Krajini

\begin{tabular}{|c|c|c|c|c|}
\hline \multirow{2}{*}{ Location } & Subpopulation & North latitude & East longitude & Altitude (m) \\
\hline \multirow{4}{*}{$\begin{array}{c}\text { Vrnograč } \\
\text { (Velika Kladuša) }\end{array}$} & $\mathrm{V} 1$ & $45^{\circ} 10^{\prime} 11^{\prime \prime}$ & $15^{\circ} 56^{\prime} 07^{\prime \prime}$ & 268,80 \\
\cline { 2 - 5 } & $\mathrm{V} 2$ & $45^{\circ} 09^{\prime} 56^{\prime \prime}$ & $15^{\circ} 58^{\prime} 13^{\prime \prime}$ & 262,10 \\
\cline { 2 - 5 } & $\mathrm{V} 3$ & $45^{\circ} 09^{\prime} 54^{\prime \prime}$ & $15^{\circ} 58^{\prime} 12^{\prime \prime}$ & 252,10 \\
\cline { 2 - 5 } & $\mathrm{V} 4$ & $45^{\circ} 10^{\prime} 06^{\prime \prime}$ & $15^{\circ} 58^{\prime} 13^{\prime \prime}$ & 258,60 \\
\hline \multirow{3}{*}{$\begin{array}{c}\text { Zaradostovo } \\
\text { (Bužim) }\end{array}$} & $\mathrm{V} 5$ & $45^{\circ} 10^{\prime} 02^{\prime \prime}$ & $15^{\circ} 58^{\prime} 19^{\prime \prime}$ & 285,20 \\
\cline { 2 - 5 } & $\mathrm{B} 6$ & $45^{\circ} 04^{\prime} 44^{\prime \prime}$ & $16^{\circ} 03^{\prime} 42^{\prime \prime}$ & 282,60 \\
\cline { 2 - 5 } & $\mathrm{B} 7$ & $45^{\circ} 04^{\prime} 44^{\prime \prime}$ & $16^{\circ} 03^{\prime} 53^{\prime \prime}$ & 271,10 \\
\cline { 2 - 5 } & $\mathrm{B} 8$ & $45^{\circ} 04^{\prime} 40^{\prime \prime}$ & $16^{\circ} 03^{\prime} 43^{\prime \prime}$ & 319,60 \\
\cline { 2 - 5 } Gornja Koprivna \\
\cline { 2 - 5 } (Cazin) & $\mathrm{B} 9$ & $45^{\circ} 04 ' 35^{\prime \prime}$ & $16^{\circ} 03^{\prime} 38^{\prime \prime}$ & 323,30 \\
\cline { 2 - 5 } & $\mathrm{C} 11$ & $44^{\circ} 58^{\prime} 47^{\prime \prime}$ & $15^{\circ} 57^{\prime} 35^{\prime \prime}$ & 503,00 \\
\cline { 2 - 5 } & $\mathrm{C} 12$ & $44^{\circ} 58^{\prime} 44^{\prime \prime}$ & $15^{\circ} 57^{\prime} 40^{\prime \prime}$ & 490,10 \\
\cline { 2 - 5 } & $\mathrm{C} 13$ & $15^{\circ} 57^{\prime \prime} 39^{\prime \prime}$ & 484,10 \\
\cline { 2 - 5 } & $\mathrm{C} 14$ & $44^{\circ} 58^{\prime} 59^{\prime \prime} 08^{\prime \prime}$ & $15^{\circ} 57^{\prime \prime} 45^{\prime \prime}$ & 498,80 \\
\cline { 2 - 5 } & $\mathrm{Ck} 15$ & $44^{\circ} 58^{\prime} 52^{\prime \prime}$ & $15^{\circ} 57^{\prime} 46^{\prime \prime} 41^{\prime \prime}$ & 486,40 \\
\hline \multirow{4}{*}{ Ck16 } & $44^{\circ} 58^{\prime} 47^{\prime \prime}$ & $15^{\circ} 57^{\prime} 35^{\prime \prime}$ & 492,00 \\
\hline
\end{tabular}


The morphological data from the measurements was processed statistically by means of the XLSTAT 2011 and STATISTICA 10 packages. The analyses encompassed the individual intra-population and inter-population variability of the quantitative properties through descriptive indicators (minimum and maximum value, arithmetic mean, standard deviation, coefficient of variation $(\mathrm{Sd} /$ mean $\mathrm{x} 100)$ and significance of differences), an analysis of variance (ANOVA) for the studied properties, and multivariant statistics through cluster analysis and principal components analysis (PCA).

\section{RESULTS OF RESEARCH - Rezultati istră̌ivanja}

Table 2. Descriptive statistical parameters

Tablica 2. Parametri deskriptivne statistike

\begin{tabular}{|c|c|c|c|c|c|c|c|c|}
\hline Subpop. & Parameter & $\begin{array}{l}\text { DPL } \\
(\mathrm{mm})\end{array}$ & $\begin{array}{l}\text { ŠPL } \\
(\mathbf{m m})\end{array}$ & $\begin{array}{l}\text { DPE } \\
(\mathbf{m m})\end{array}$ & OBL & UL & ŠPL/DPL & ŠPL/UDL \\
\hline 1 & 2 & 3 & 4 & 5 & 6 & 7 & 8 & 9 \\
\hline \multirow{3}{*}{ V1 } & $\overline{\bar{x}}(\mathrm{~mm})$ & 15.73 & 5.78 & 1.72 & 2.33 & 1.35 & 0.37 & 0.33 \\
\hline & $\mathrm{s}(\mathrm{mm})$ & 2.33 & 0.95 & 0.47 & 0.72 & 0.47 & 0.05 & 0.04 \\
\hline & CV (\%) & 14.86 & 16.44 & 27.34 & 31.02 & 35.40 & 0.13 & 0.14 \\
\hline \multirow{3}{*}{$\mathrm{V} 2$} & $\overline{\mathbf{x}}(\mathrm{mm})$ & 18.28 & 7.58 & 1.13 & 2.46 & 1.95 & 0.41 & 0.39 \\
\hline & $\mathrm{s}(\mathrm{mm})$ & 2.90 & 1.14 & 0.23 & 0.67 & 0.21 & 0.05 & 0.05 \\
\hline & CV (\%) & 15.88 & 15.10 & 20.61 & 27.46 & 11.19 & 0.14 & 0.13 \\
\hline \multirow{3}{*}{ V3 } & $\overline{\mathbf{x}}(\mathrm{mm})$ & 18.45 & 7.21 & 1.30 & 2.46 & 1.66 & 0.39 & 0.37 \\
\hline & $\mathrm{s}(\mathrm{mm})$ & 3.53 & 1.25 & 035 & 0.63 & 0.47 & 0.06 & 0.06 \\
\hline & CV (\%) & 19.17 & 17.36 & 27.20 & 25.78 & 28.58 & 0.17 & 0.17 \\
\hline \multirow{3}{*}{ V4 } & $\overline{\mathbf{x}}(\mathrm{mm})$ & 17.96 & 7.01 & 1.12 & 2.57 & 1.65 & 0.39 & 0.37 \\
\hline & $\mathrm{s}(\mathrm{mm})$ & 2.32 & 0.83 & 0.26 & 0.57 & 0.47 & 0.04 & 0.04 \\
\hline & $\mathrm{CV}(\%)$ & 12.96 & 11.87 & 23.68 & 22.41 & 28.88 & 0.12 & 0.12 \\
\hline \multirow{3}{*}{ V5 } & $\overline{\mathbf{x}}(\mathrm{mm})$ & 19.16 & 7.55 & 1.07 & 2.54 & 1.80 & 0.39 & 0.37 \\
\hline & $\mathrm{s}(\mathrm{mm})$ & 2.89 & 1.08 & 0.21 & 0.59 & 0.39 & 0.05 & 0.04 \\
\hline & $\mathrm{CV}(\%)$ & 15.10 & 14.30 & 20.40 & 23.23 & 22.07 & 0.12 & 0.12 \\
\hline \multirow{3}{*}{ B6 } & $\overline{\mathbf{x}}(\mathrm{mm})$ & 20.08 & 6.44 & 2.04 & 2.33 & 1.52 & 0.32 & 0.29 \\
\hline & $\mathrm{s}(\mathrm{mm})$ & 3.22 & 0.94 & 0.51 & 0.65 & 0.50 & 0.04 & 0.04 \\
\hline & $\mathrm{CV}(\%)$ & 16.05 & 14.70 & 24.94 & 27.89 & 32.84 & 0.14 & 0.14 \\
\hline \multirow{3}{*}{ B7 } & $\overline{\mathbf{x}}(\mathrm{mm})$ & 17.45 & 6.32 & 1.74 & 2.40 & 1.72 & 0.36 & 0.33 \\
\hline & $\mathrm{s}(\mathrm{mm})$ & 3.08 & 1.26 & 0.58 & 0.77 & 0.44 & 0.05 & 0.05 \\
\hline & $\mathrm{CV}(\%)$ & 17.68 & 19.95 & 33.43 & 32.12 & 26.00 & 0.15 & 0.16 \\
\hline \multirow{3}{*}{ B8 } & $\overline{\bar{x}}(\mathrm{~mm})$ & 18.24 & 6.25 & 1.78 & 2.51 & 1.72 & 0.34 & 0.31 \\
\hline & $\mathrm{s}(\mathrm{mm})$ & 3.43 & 1.17 & 0.47 & 0.68 & 0.44 & 0.04 & 0.04 \\
\hline & CV (\%) & 18.80 & 18.86 & 26.86 & 27.16 & 26.00 & 0.13 & 0.14 \\
\hline \multirow{3}{*}{ B9 } & $\overline{\mathbf{x}}(\mathrm{mm})$ & 15.37 & 5.13 & 1.78 & 2.42 & 1.85 & 0.33 & 0.29 \\
\hline & $\mathrm{s}(\mathrm{mm})$ & 2.45 & 1.18 & 0.57 & 0.72 & 0.35 & 0.04 & 0.04 \\
\hline & $\mathrm{CV}(\%)$ & 15.96 & 23.00 & 32.25 & 30.08 & 18.84 & 0.13 & 0.14 \\
\hline
\end{tabular}




\begin{tabular}{|c|c|c|c|c|c|c|c|c|}
\hline 1 & 2 & 3 & 4 & 5 & 6 & 7 & 8 & 9 \\
\hline \multirow{3}{*}{ C10 } & $\overline{\mathbf{x}}(\mathrm{mm})$ & 15.25 & 5.77 & 1.54 & 2.68 & 1.75 & 0.38 & 0.34 \\
\hline & $\mathrm{s}(\mathrm{mm})$ & 2.71 & 0.91 & 0.51 & 0.55 & 0.43 & 0.04 & 0.04 \\
\hline & CV (\%) & 17.81 & 15.78 & 32.90 & 20.84 & 24.62 & 0.11 & 0.12 \\
\hline \multirow{3}{*}{ C11 } & $\overline{\bar{x}}(\mathrm{~mm})$ & 15.81 & 6.07 & 1.65 & 2.66 & 1.50 & 0.38 & 0.34 \\
\hline & $\mathrm{s}(\mathrm{mm})$ & 2.42 & 1.20 & 0.50 & 0.57 & 0.50 & 0.05 & 0.05 \\
\hline & CV (\%) & 15.30 & 19.81 & 30.35 & 21.38 & 33.31 & 0.14 & 0.15 \\
\hline \multirow{3}{*}{$\mathrm{C} 12$} & $\overline{\mathbf{x}}(\mathrm{mm})$ & 15.89 & 5.58 & 1.57 & 2.60 & 1.49 & 0.35 & 0.32 \\
\hline & $\mathrm{s}(\mathrm{mm})$ & 2.15 & 0.95 & 0.51 & 0.64 & 0.50 & 0.06 & 0.05 \\
\hline & $\mathrm{CV}(\%)$ & 13.54 & 17.14 & 32.32 & 24.56 & 33.55 & 0.17 & 0.18 \\
\hline \multirow{3}{*}{ C13 } & $\overline{\mathbf{x}}(\mathrm{mm})$ & 17.05 & 6.28 & 1.77 & 2.54 & 1.33 & 0.37 & 0.33 \\
\hline & $\mathrm{s}(\mathrm{mm})$ & 2.03 & 0.85 & 0.41 & 0.61 & 0.47 & 0.05 & 0.04 \\
\hline & $\mathrm{CV}(\%)$ & 11.98 & 13.55 & 23.63 & 24.32 & 35.41 & 0.13 & 0.14 \\
\hline \multirow{3}{*}{ C14 } & $\overline{\mathbf{x}}(\mathrm{mm})$ & 16.81 & 6.40 & 1.53 & 2.59 & 1.60 & 0.38 & 0.35 \\
\hline & $\mathrm{s}(\mathrm{mm})$ & 2.54 & 0.78 & 0.48 & 0.69 & 0.49 & 0.05 & 0.05 \\
\hline & CV $(\%)$ & 15.13 & 12.29 & 31.27 & 26.92 & 30.66 & 0.13 & 0.14 \\
\hline \multirow{3}{*}{ Ck15 } & $\overline{\mathbf{x}}(\mathrm{mm})$ & 17.82 & 5.63 & 1.84 & 2.50 & 1.91 & 0.32 & 0.29 \\
\hline & $\mathrm{s}(\mathrm{mm})$ & 4.17 & 0.84 & 0.27 & 0.64 & 0.28 & 0.04 & 0.04 \\
\hline & CV (\%) & 23.40 & 14.94 & 14.95 & 25.61 & 14.97 & 0.14 & 0.13 \\
\hline \multirow{3}{*}{ Ck16 } & $\mathbf{x}(\mathrm{mm})$ & 14.64 & 6.52 & 1.39 & 2.62 & 1.32 & 0.44 & 0.41 \\
\hline & $\mathrm{s}(\mathrm{mm})$ & 1.72 & 0.71 & 0.39 & 0.61 & 0.47 & 0.05 & 0.05 \\
\hline & CV $(\%)$ & 11.75 & 10.88 & 28.18 & 23.27 & 35.54 & 0.13 & 0.13 \\
\hline
\end{tabular}

The results of the intra-population descriptive statistics for the studied properties of the leaf (Table 2) show that the V2 subpopulation (locality Vrnograč) had the lowest variability of the depth of indentations of leaf edges property (UL), with the coefficient of variability of $11.19 \%$, while the $\mathrm{C}_{\mathrm{k}} 16$ control subpopulation (locality Cazin) had the highest coefficient of $35.54 \%$. In terms of petiole length (DPE), the control subpopulation $\mathrm{C}_{\mathrm{k}} 15$ (locality Cazin) had the lowest coefficient of variability of $14.95 \%$, while the B7 subpopulation in Bužim had the highest coefficient of variability for this property (33.43\%).

A descriptive analysis of the inter-population variability determined the average measurements of the sweet chestnut leaf in the region of Bosanska Krajina: blade length $17.31 \mathrm{~mm} \pm 3.16 \mathrm{~mm}$, blade width $6.43 \mathrm{~mm} \pm 1.23 \mathrm{~mm}$, petiole length $1.55 \mathrm{~mm} \pm 0.52 \mathrm{~mm}$, ratio between blade width and length $0.37 \mathrm{~mm} \pm 0.06 \mathrm{~mm}$, ratio between blade width and total leaf length $0.34 \mathrm{~mm} \pm 0.05 \mathrm{~mm}$, leaf base shape $2.51 \pm$ 0.65 and depth of indentations of leaf edges $1.63 \pm 0.48$ (Table 3 ). 
Table 3. Descriptive statistics of intra-population variability of studied properties

Tablica 3. Deskriptivna statistika međupopulacijske varijabilnosti istraživanih subpopulacija

\begin{tabular}{|c|c|c|c|c|c|c|}
\hline Studied leaf properties & $\mathrm{N}$ & Mean & $\begin{array}{c}\text { Stand. } \\
\text { dev. }\end{array}$ & Min & Max & $\mathrm{CV}$ \\
\hline Blade length (mm) & 4020 & 17.31 & 3.16 & 9.20 & 30.80 & 18.28 \\
\hline Blade width (mm) & 4020 & 6.43 & 1.23 & 2.50 & 12.00 & 19.18 \\
\hline Petiole length (mm) & 4020 & 1.55 & 0.52 & 0.50 & 6.70 & 33.70 \\
\hline $\begin{array}{c}\text { Ratio between blade width and } \\
\text { length (mm) }\end{array}$ & 4020 & 0.37 & 0.06 & 0.13 & 0.62 & 0.16 \\
\hline $\begin{array}{c}\text { Ratio between blade width and } \\
\text { total leaf length (mm) }\end{array}$ & 4020 & 0.34 & 0.05 & 0.10 & 0.57 & 0.17 \\
\hline Leaf base shape & 4020 & 2.51 & 0.65 & 1.00 & 3.00 & 26.15 \\
\hline $\begin{array}{c}\text { Depth of indentations of leaf } \\
\text { edges }\end{array}$ & 4020 & 1.63 & 0.48 & 1.00 & 2.00 & 29.56 \\
\hline
\end{tabular}

Table 4. Analysis of variance of groups for studied properties of sweet chestnut leaf

Tablica 4. Analiza varijanse grupa za istraživana svojstva lista pitomog kestena

\begin{tabular}{|c|c|c|c|c|c|c|}
\hline Property & $\begin{array}{c}\text { Source of } \\
\text { variability }\end{array}$ & $\begin{array}{c}\text { Freedom } \\
\text { levels }\end{array}$ & $\begin{array}{l}\text { Sum of } \\
\text { squares }\end{array}$ & $\begin{array}{l}\text { Square } \\
\text { mean }\end{array}$ & $\mathrm{F}$ & $\begin{array}{c}\text { Sig. } \\
(\operatorname{Pr}>\mathrm{F})\end{array}$ \\
\hline \multirow{2}{*}{$\begin{array}{l}\text { DPL - leaf blade } \\
\text { length }(\mathrm{mm})\end{array}$} & $\begin{array}{l}\text { Between groups } \\
\text { Within groups }\end{array}$ & $\begin{array}{c}15 \\
4004\end{array}$ & $\begin{array}{c}8632.765 \\
31603.585\end{array}$ & $\begin{array}{c}575.518 \\
7.893\end{array}$ & 72.915 & $<0.0001$ \\
\hline & Total & 4019 & 40236.350 & & & \\
\hline \multirow{2}{*}{$\begin{array}{l}\text { ŠPL - leaf blade } \\
\text { width }(\mathrm{mm})\end{array}$} & $\begin{array}{l}\text { Between groups } \\
\text { Within groups }\end{array}$ & $\begin{array}{c}15 \\
4004\end{array}$ & $\begin{array}{l}1776.798 \\
4338.041\end{array}$ & $\begin{array}{c}118.453 \\
1.083\end{array}$ & 109.332 & $<0.0001$ \\
\hline & Total & 4019 & 6114.839 & & & \\
\hline \multirow{2}{*}{$\begin{array}{l}\text { DPE - petiole length } \\
(\mathrm{mm})\end{array}$} & $\begin{array}{l}\text { Between groups } \\
\text { Within groups }\end{array}$ & $\begin{array}{c}15 \\
4004\end{array}$ & $\begin{array}{l}318.324 \\
789.909\end{array}$ & $\begin{array}{c}21.222 \\
0.197\end{array}$ & 107.571 & $<0.0001$ \\
\hline & Total & 4019 & 1108.232 & & & \\
\hline \multirow{2}{*}{$\begin{array}{c}\text { ŠPL/DPL - ratio } \\
\text { between leaf blade } \\
\text { width and length } \\
(\mathrm{mm})\end{array}$} & $\begin{array}{l}\text { Between groups } \\
\text { Within groups }\end{array}$ & $\begin{array}{c}15 \\
4004 \\
\end{array}$ & $\begin{array}{c}3.181 \\
11.453 \\
\end{array}$ & $\begin{array}{l}0.212 \\
0.003 \\
\end{array}$ & 74.130 & $<0.0001$ \\
\hline & Total & 4019 & 14.633 & & & \\
\hline \multirow{2}{*}{$\begin{array}{l}\text { ŠPL/UDL - ratio } \\
\text { between leaf blade } \\
\text { width and total leaf } \\
\text { length }(\mathrm{mm})\end{array}$} & $\begin{array}{c}\text { Between groups } \\
\text { Within groups }\end{array}$ & $\begin{array}{c}15 \\
4004 \\
\end{array}$ & $\begin{array}{c}3.574 \\
10.463 \\
\end{array}$ & $\begin{array}{l}0.238 \\
0.003 \\
\end{array}$ & 91.181 & $<0.0001$ \\
\hline & Total & 4019 & 14.037 & & & \\
\hline \multirow{2}{*}{$\begin{array}{c}\mathrm{OBL} \text { - leaf base } \\
\text { shape }\end{array}$} & $\begin{array}{l}\text { Between groups } \\
\text { Within groups }\end{array}$ & $\begin{array}{c}15 \\
4004\end{array}$ & $\begin{array}{c}45.532 \\
1694.417\end{array}$ & $\begin{array}{l}3.035 \\
0.423\end{array}$ & 7.173 & $<0.0001$ \\
\hline & Total & 4019 & 1739.949 & & & \\
\hline \multirow{2}{*}{$\begin{array}{c}\text { UL - depth of } \\
\text { indentations of leaf } \\
\text { edges }\end{array}$} & $\begin{array}{c}\text { Between groups } \\
\text { Within groups }\end{array}$ & $\begin{array}{c}15 \\
4004\end{array}$ & $\begin{array}{l}130.593 \\
804.532\end{array}$ & $\begin{array}{l}8.706 \\
0.201\end{array}$ & 43.329 & $<0.0001$ \\
\hline & Total & 4019 & 935.124 & & & \\
\hline
\end{tabular}


The analysis of variance for the studied properties of the leaf imply the existence of statistically significant differences (Sig.<0.01) among the groups, which shows a pronounced inter-population variability of the studied properties in comparison to intra-population variability (Table 4).

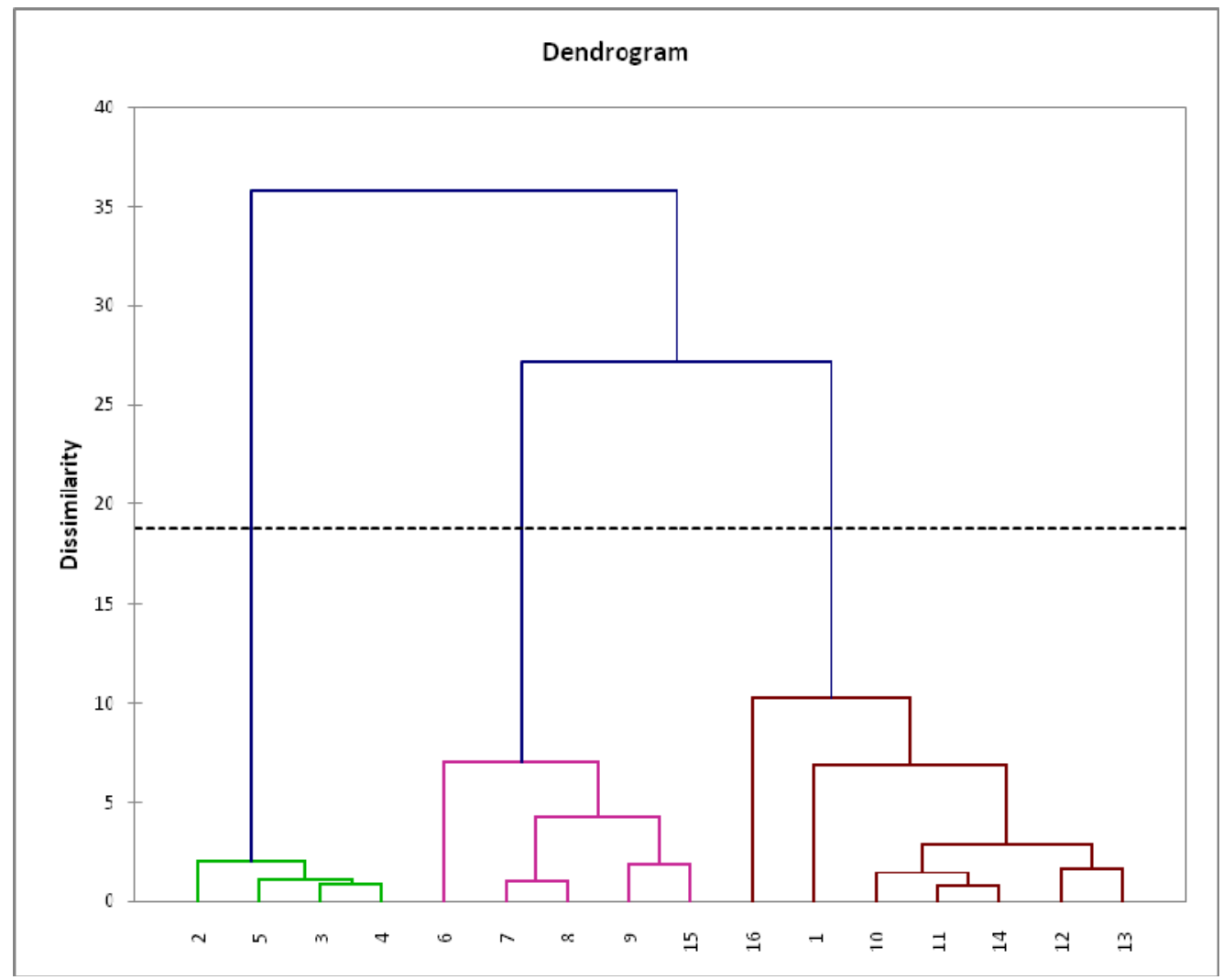

Figure 1. Dendrogram of grouping of studied subpopulations by morphological properties of the sweet chestnut (Castanea sativa Mill.)

Slika 1. Dendrogram grupiranja istraživanih subpopulacija prema morfološkim karakteristikama pitomog kestena (Castanea sativa Mill.)

An agglomerative hierarchical clustering (AHC) analysis was used to produce a diagram (Figure 1) for the 16 studied sweet chestnut subpopulations relating to the analysed properties of the sweet chestnut leaf. The topology of the dendrogram clearly shows the existence of three main groups of the studied subpopulations relating to the seven studied properties of the leaf. Subpopulations V1, C10, C11, C12, C13, C14 and Ck16 are the most akin according to all studied morphological properties of the sweet chestnut leaf and they make the first group. Subpopulations V2, V3, V4 and V5 are the closest one to another in terms of all studied properties and are sorted in the second 
group, while the third group comprises the four subpopulations from Bužim (B6, B7, B8 and B9) and the Ck15 control subpopulation from Cazin. Homogeneousness within all groups is perceived relative to the geographical origin of the subpopulations.

Table 5. Eigenvalues and cumulative variability in the first seven PC factors (values in bold mark cumulative variability of the first three PC factors)

Tablica 5. Eigen-vrijednosti $i$ kumulativna varijabilnost sadržana u prvih 7 PC faktora (boldirane vrijednosti označavaju kumulativne varijabilnosti prva tri PC-faktora)

\begin{tabular}{|c|c|c|c|c|c|c|c|}
\hline & F1 & F2 & F3 & F4 & F5 & F6 & F7 \\
\hline Eigenvalue & 3.481 & 1.983 & 0.945 & 0.465 & 0.116 & 0.008 & 0.002 \\
\hline Variability (\%) & $\mathbf{4 9 . 7 2 3}$ & $\mathbf{2 8 . 3 3 4}$ & $\mathbf{1 3 . 5 0 3}$ & 6.647 & 1.655 & 0.114 & 0.024 \\
\hline Cumulative \% & $\mathbf{4 9 . 7 2 3}$ & $\mathbf{7 8 . 0 5 7}$ & $\mathbf{9 1 . 5 6 0}$ & 98.207 & 99.862 & 99.976 & 100.000 \\
\hline
\end{tabular}

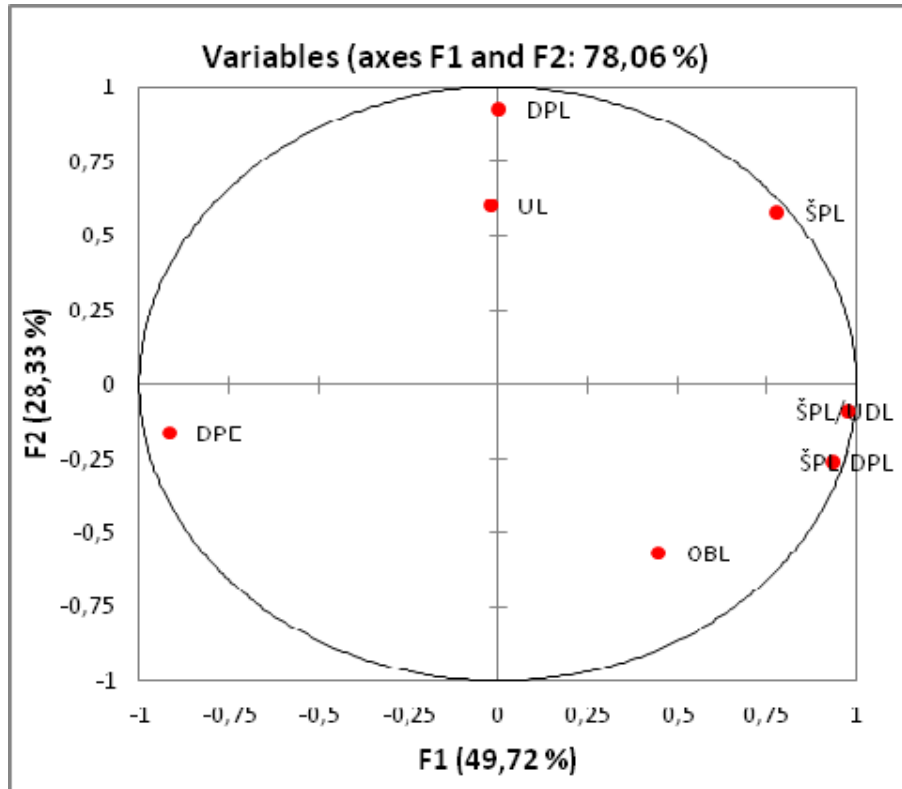

Picture 2. Principal component method (PC1 vs. PC2) for morphological properties of the leaf Slika 2. Metoda glavnih komponenata (PC1 vs. PC2) za morfološke karakteristike lista

A principal component analysis (PCA) was used as a classification technique in order to classify the subpopulations relating to the studied morphological properties of the sweet chestnut leaf, and on the basis of the calculated eigenvalues, the individual contribution of each studied variable of the leaf in the classification of subpopulations was determined. The morphological characteristics of the leaf were used as a variable for the PCA, while the studied subpopulations labelled with numbers 1 through 16 were used as cases. The results of the PCA of the morphological properties of the sweet chestnut leaf show that the cumulative variability in the first three PC-factors amounts to $91.56 \%$, with the expected biggest 
participation of the first PC1 factor of $49.72 \%$, while the PC2 and PC3 factors contribute a lot less to total variability, $28.33 \%$ and $13.5 \%$ respectively (Table 5 ). A comparison between the PC1 and PC2 factors of the PCA for the morphological properties of the leaf and the studied subpopulations is shown in figures 2 and 3.

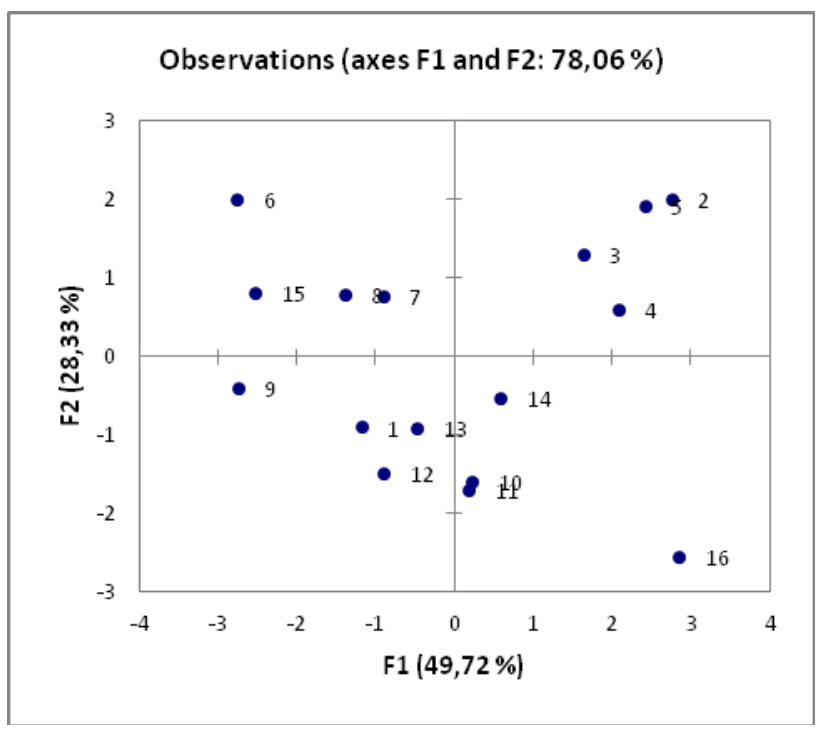

Picture 3. Principal component method (PC1 vs. PC2) for the studied subpopulations Slika 3. Metoda glavnih komponenata (PC1 vs. PC2) za proučavane subpopulacije

\section{DISCUSSION AND CONCLUSIONS - Rasprava i zaključci}

In this paper, a research of the intra-population and inter-population variability of the sweet chestnut (Castanea sativa Mill.) in the region of Bosanska Krajina (localities Gornja Koprivna in Cazin, Zaradostovo in Bužim and Vrnograč in Velika Kladuša) was made on the basis of seven morphological properties of the sweet chestnut leaf. An analysis of the morphological properties of the sweet chestnut in the region of Bosanska Krajina in its natural populations was used to establish with statistical methods the interaction between the genotype and environment and raise awareness about the need to preserve the natural populations of the sweet chestnut, because they represent the main source of the variability of genetic material of this species. Since the development of any population is based on the genetic properties as well as various impacts of the environment, the morphometric and phenological methods are good indicators of the interaction of the genome and habitat. There are several studies which use different morphological analyses to estimate the variability of sweet chestnut populations and which confirm that the parameters of the nut, leaf and cupule can be appropriate variables for establishing the level of phenotype variability among natural populations of the sweet chestnut. For example, 
ARAVANOPOULOS ET AL. (2005) studied the variability of the leaf in sweet chestnut populations in Greece. Zarafshar et al. (2010) studied the phenotype variability of natural sweet chestnut populations in northern Iran, also on the basis of leaf morphology, while SERDAR AND KURT (2011), tried to determine parameters important for differentiation of genotypes of the sweet chestnut on the basis of morphological parameters of the leaf in northern Turkey. ERTAN (2007), BOLVANSKY AND UZIK (2005), and ARAVANOPOULOS ET AL. (2001) detected considerable differences between the units and populations of the sweet chestnut on the basis of morphology of the leaf and nut. ÁlvAREZ-ÁlvAREZ ET AL. (2006) studied the variability of sweet chestnut cultivars in north-eastern Galicia on the basis of the dimensions of the leaf, nut and cupule, and the results they got suggest the possibility of differentiation of local cultivars in the region on the basis of the dimensions of the leaf and nut as predictor variables, while the dimensions of the cupule have negligible impact. RAMOS-CAMBER ET AL. (2005), SOLAR ET AL. (2005), KOYUNCU ET AL. (2008), PANDIT ET AL. (2009) and many others studied the variability of the sweet chestnut by using a combination of morphological, phonological and molecular methods.

A descriptive analysis of populations detected more pronounced intrapopulation variability in comparison to inter-population variability of the studied properties of the sweet chestnut leaf. It has been established that inter-population variability is more pronounced than inter-population variability in other species also. When researching the morphological characteristics of the pedunculate oak (Quercus robur L.) in Bosnia-Herzegovina, BALLIAN ET AL. (2010) established bigger differences within populations than among populations in all studied properties.

An analysis of variance (ANOVA) was carried out in order to confirm the intrapopulation and inter-population variability of the studied properties of the leaf, and the existence of statistically significant variability among the subpopulations at the significance level of 0.01 was established for all studied properties of the sweet chestnut leaf.

An agglomerative hierarchical clustering (AHC) analysis was used to detect possible similarities and differences between the 16 studied subpopulations of the sweet chestnut in terms of morphological properties of the leaf. Three main groups were sorted out and all of them are homogeneous with respect to the geographical origin of the studied subpopulations.

A principal component analysis (PCA) established that the cumulative variability for the first two PC factors is $78 \%$. With an analysis of the established eigenvalues, it can be concluded that the first two PC factors divide the subpopulations on the basis of the leaf size (DPL, ŠPL, DPE, ŠPL/DPL and ŠPL/UDL), while the third PC divides the subpopulations on the basis of the depth of indentations of leaf edges (UL).

The results point to the existence of variability within and among the studied subpopulations, which means that the studied morphological properties of the leaf can be appropriate variables for determining phenotype variability in sweet chestnut populations. 
In the coming period, the results should be confirmed at the molecular-genetic level, and research on the morphological properties of the nut and cupule of the sweet chestnut in the region of Bosanska Krajina should be carried out.

\section{REFERENCES - Literatura}

Álvarez-Álvarez, P., Barrio-Anta, M., Diégues-Arnanda, U. (2006): Differentiation of sweet chestnut (Castanea sativa Mill.) cultivars by leaf, nut and burr dimensions. Forestry. Institute of Chatered Foresters.

Aravanopoulos, F.A., Drouzas, A.D., Alizoti, P.G. (2001): Electrophoretic and quantitative variation in chestnut (Castanea sativa Mill.) in Hellenic populations in old-growth natural and coppice stands. For. Snow Landsc. Res., 16 (3): 429-434.

Aravanopoulos, F.A., Bucci, G., Akkak, A., Blanco Silva, R., Botta, R., Buck, E., Cherubini, M., Drouzas, A.D., Fernandez-Lopez, J., Mattioni, C., Marinoni, D., PAPADIMA, A., RUSSEL, K., ZAS, R., VILLANI F. (2005): Molecular population genetics and dinamics of chestnut (Castanea sativa Mill.) in Europe: Inferences for gene conservation and tree improvement. Acta Hort. (ISHS) 693: 403-412.

Ballian, D., MemišEvić, M., Bogunić, F., Bašlć, N., MaRković, M., KAJBA, D. (2010): Morfološka varijabilnost hrasta lužnjaka (Quercus robur L.) na području Hrvatske i zapadnog Balkana. Šumarski list br. 7-8, CXXXIV, 371-386.

BOLVANSKY, M., UZIK, M. (2005): Morphometric variation and differentiation of European Chestnut (Castanea sativa Mill.) in Slovakia. Biologia (Bratislava), 60 (4): 423-429.

BRUSCHI, R., GRossonI, R., BussotII, F. (2003): Within- and among-tree variation in leaf morphology of Quercus petraea (Matt.) Liebl. natural populations. Trees, 17:164-172.

ERTAN, E. (2007): Variability in leaf and fruit morphology and in fruit composition of chestnuts (Castanea sativa Mill.) in the Nazilli region of Turkey. Genet Resour Crop Evol 54:691-699.

FERNÁNDEZ-LÓPEZ, J., ALIA, R. (2003): Technical Guidelines for genetic conservation and use for chestnut (Castanea sativa) - EUFORGEN-NH (EUFORGEN- Noble Hardwoods), EUR (Regional Office for Europe).

Koyuncu, F., Cetinbas, M., Yildrim, A.N. (2008): Pomological Properties and Proximate Analysis of Nativ Chestnut (Castanea sativa Mill.). Journal of the American Pomological Society, Vol 62, Number 3, pp. 300-306.

Mujagić-Pašlć, A., Ballian, D. (2011): Systematical position of sweet chestnut (Castanea sativa Mill.) within the genus Castanea in Bosnia and Herzegovina. Naše šume. Časopis za unapređenje šumarstva, hortikulture i očuvanja okoline. Broj 24-25, godina X, Sarajevo. 
MuJIĆ, I., AlIBABIĆ, V., IBRAHIMPAŠIĆ, J., JAHIĆ, S., MuSLIMOVIĆ, D. (2006): Characteristics of the chestnuts from Una Sana Canton in comparison to other chestnut varieties and the influence of different preservation techniques on nutritive values. ISHS Acta Horticulturae 768: XXVII International Horticultural Congress - IHC: International Symposium on The Role of Postharvest Technology in the Globalisation of Horticulture.

MujIĆ, I., Alibabić, A., ŽIVKović, J., JahIĆ, S., Jokić, S., PRgomet, Ž., TUZLAK, Z. (2010): Morphological characteristics of chestnut Castanea sativa from the area Una-Sana Canton. Journal Central European Agriculture, Volume 11, No.2, 185-190.

Neophytou, CH., Palli, G., Dounavi, A., Aravanopoulos, F.A. (2007): Morphological differentiation and hybridization between Quercus alnifolia Poech and Quercus coccifera L. (Fagaceae) in Cyprus. Silvae Genet., 56 (6):271-277.

PANDIT, A.H., KouR, A., WANI, M.S., MIR, M.A. (2009): Genetic resources of chestnut in Kashmir valley. Acta Hort. (ISHS) 815:51-56.

Ramos-Cabrer, A.M., Periera-Lorenzo, S. (2005): Genetic relationship between Castanea sativa Mill. trees from north-western to south Spain based on morphological traits and isoenzymes. Genetic Resources and Crop Evolution 52: 879-890.

Serdar, U., KURT, N. (2011): Some Leaf Characteristics are Better Morphometric Discriminators for Chestnut Genotypes. J. Agr. Sci. Tech. (2011) Vol. 13: 885-894.

SKENDER, A. (2010): Genetska i pomološka varijabilnost populacija pitomog kestena u Bosni i Hercegovini. Doktorska disertacija, Univerzitet u Sarajevu, Poljoprivredno-prehrambeni fakultet, Sarajevo.

Solar, A., Podjavoršek, A., Štampar, F. (2005): Phenotypic and genotypic diversity of European chestnut (Castanea sativa Mill.) in Slovenia - opportunity for genetic improvement. Genetic Resources and Crop Evolution 52: 381-394.

Sučı́, J. (1953): O arealu pitomog kestena (Castanea sativa Mill.) na području Srebrenice, sa kratkim osvrtom na ostala nalazišta kestena u NR BiH. Institut za naučna šumarska istraživanja u Sarajevu, Sarajevo, knjiga II, sveska 4.

TREŠTIĆ, T., DAUTBAŠIĆ, M., MuJeZINOVIĆ, O. (2009): Štetni organizmi ploda pitomog kestena. Naše šume. Časopis za unapređenje šumarstva, hortikulture i očuvanja okoline. Broj 14-15, godina VIII, Sarajevo.

UPOV (1989): INTERNATIONAL UNION FOR THE PROTECTION OF NEW VARIETIES OF PLANTS. Guidelines for the conduct of tests for distinctness, homogeneity and stability: Chestnut (Castanea sativa Mill.). Geneve, p. 23.

UsČUPLIĆ, M., MIDžIĆ, S. (1967): Razvoj raka pitomog kestena u Cazinskoj krajini. Narodni šumar, Savez inženjera i tehničara šumarstva i drvne industrije SR Bosne i Hercegovine, Sarajevo. 7-8:379-387. 
WRABER, M. (1958): Biljnosociološki prikaz kestenovih šuma Bosne i Hercegovine. Godišnjak Biološkog instituta Univerziteta u Sarajevu, Sarajevo, god. IX, fasc. 12:139-182.

Zarafshar, M., Akbarinia, M., Bruschi, R., Hosseiny, S. M., YousefZadeh, H., TAieby, M., SATTARIAN, A. (2010): Phenotypic variation in chestnut (Castanea sativa Mili.) natural populations in Hyrcanian forest (north of Iran), revealed by leaf morphometrics. Folia oecol., 37:113-121.

ZeLIĆ, J. (1998): Pitanje autohtonosti i dalji uzgoj pitomog kestena (Castanea sativa Mill.) u Požeškom gorju. Šumarski list, Zagreb, 11-12, CXXII, 525-536.

XLSTAT 2011: http://www.download3k.com/Business-Finance/PersonalFinance/Download- XLSTAT-Win.html

STATISTICA 10: http://www.statsoft.com/support/free-statistica-10-trial/

\section{SAŽETAK}

Pitomi kesten (Castanea sativa Miller) je prastara vrsta tercijarne flore koja se očuvala kroz ledeno doba do danas. U Bosanskoj Krajini (sjeverozapadna Bosna), ova vrsta se javlja u sklopu prirodnih populacija, naročito u Cazinu, Bužimu i Velikoj Kladuši. Iako se ovo područje smatra jednim od bogatijih kestenovih područja u Bosni i Hercegovini, još uvijek nema informacija o fenotipskoj varijabilnosti ovih populacija. Cilj ovog istraživanja jeste utvrditi unutarpopulacijsku i međupopulacijsku varijabilnost prirodnih populacija kestena u Bosanskoj Krajini na osnovu morfologije lista. Selekcionisano je 16 subpopulacija i 146 stabala na području Cazina (Gornja Koprivna), Bužima (Zaradostovo) i Velike Kladuše (Vrnograč), a sa svakog stabla je sabrano po 30 listova. Ukupljeno je skupljeno 4.380 listova ujednačenih dimenzija na kojima su mjerena i analizirana svojstva: dužina plojke lista (DPL), širina plojke lista (ŠPL), dužina peteljke (DPE), oblik baze lista (OBL) i usječenost oboda lista (UL). Iz poznatih vrijednosti, izračunati su odnosi širina plojke lista/dužina plojke lista (ŠPL/DPL) i širina plojke lista/ukupna dužina lista (ŠPL/UDL). Jednostrukom analizom varijanse (ANOVA) utvrđeno je postojanje varijabilnosti kako između istraživanih subpopulacija, tako i unutar subpopulacija. Aglomerativnom cluster analizom (AHC) istraživane subpopulacije su se grupirale u tri grupe na osnovu morfologije lista, dok je metoda glavnih komponenata (PCA) korištena kako bi se izvršilo razdvajanje istraživanih morfoloških svojstava lista u međusobno nezavisne komponente. Kumulativna varijabilnost za prva tri PC faktora iznosi 91,5\%, sa najvećim učešćem prvog PC1 faktora sa 49,7 \% varijabilnosti. Na osnovu dobivenih rezultata, može se zaključiti da su morfološki parametri lista pogodne varijable za utvrđivanje nivoa varijabilnosti u prirodnim populacijama pitomog kestena. 